\title{
VILLAS, CIDADES E MUNICÍPIOS: DESCENTRALIZAÇÃO E AUTONOMIA LOCAL COMO PERMANÊNCIAS DA COLONIZAÇÃO PORTUGUESA NA REPÚBLICA BRASILEIRA
}

\author{
VILLAS, CITIES AND COUNTIES: DECENTRALIZATION AND LOCAL \\ AUTONOMY AS PERMANENCY OF PORTUGUESE COLONIZATION IN THE \\ BRAZILIAN REPUBLIC
}

\author{
${ }^{1}$ Luciano Machado de Souza
}

\section{RESUMO}

O arranjo federativo brasileiro desperta atenção pelo grau de autonomia municipal, opção normativa que ampliou a descentralização do poder e possibilitou o desenvolvimento de políticas públicas mais adequadas às peculiaridades locais. $\mathrm{O}$ enfoque político-jurídico, sob perspectiva historiográfica, visava investigar se a arquitetura institucional foi decorrência de dissociada inovação constituinte ou recebeu influências histórico-culturais. Demonstrando-se a desnecessidade de comparação, a análise da posição do Município nos períodos colonial e imperial permitiu verificar permanências no exercício do poder local que fortaleciam-se nos períodos democráticos da República, culminando com a atual conformação estabelecida na Constituição Federal de 1988. Sem aprofundar-se nas polêmicas conceituais que envolvem estudiosos do Direito do Estado, ou nos problemas econômico-financeiros gerados pelo modelo, este trabalho demonstra a importância do estudo da administração colonial para o desenvolvimento dos Municípios brasileiros.

Palavras-chave: Municípios, Descentralização, Permanências, Colonização portuguesa

\begin{abstract}
The Brazilian federative arrangement arouses attention by its degree of municipal autonomy, rule of law option which increased the decentralization of power and enabled the development of more appropriate public policies to local peculiarities. The legal political approach under historiographical perspective aimed to investigate whether the institutional architecture originated from dissociated constituent innovation or received historical and cultural influences. Demonstrating the unnecessary comparison, the analysis of county's position in colonial and imperial periods has shown permanency in the exercise of local power that strengthened in the democratic periods of the Republic, culminating in the current resemblance established in the Federal Constitution of 1988. Without deepen conceptual controversies involving State Law scientists, or regarding economic and financial problems generated by the model, this article demonstrates the importance of studying the colonial administration for the development of Brazilian Counties.
\end{abstract}

Keywords: Counties, Decentralisation, Permanency, Portuguese colonization

\footnotetext{
${ }^{1}$ Doutor em Direito pela Universidade Federal do Paraná - UFPR, Curitiba - PR (Brasil). Professor da Escola da Magistratura do Paraná - EMAP, Curitiba - PR (Brasil).

E-mail: lucmachado@hotmail.com
} 


\begin{abstract}
Ao fim desta súmula do regime municipal adotado nos diversos países do velho e do novo continente, podemos concluir que o mais aperfeiçoado é o nosso, juridicamente concebido e tecnicamente organizado, dentro do sistema constitucional brasileiro. Se há deficiências no seu funcionamento, são menos devidas às falhas da instituição que aos erros freqüentes cometidos pela inexperiência ou inépcia dos administradores locais. A nosso ver, os defeitos da administração municipal brasileira não estão nas leis, mas, sim, na maneira de aplicá-las. Corrijam-se os administradores, e corrigidas estarão as falhas das administrações. (Hely Lopes Meirelles)
\end{abstract}

\title{
INTRODUÇÃO
}

O arranjo federativo brasileiro tem despertado atenção pelo grau de autonomia concedido aos municípios no último processo constituinte; de fato, a opção implica alargada descentralização do poder. Se, por um lado, os municípios se beneficiam de prerrogativas que permitem o desenvolvimento de políticas públicas mais adequadas às peculiaridades locais, por outro já é possível detectar problemas econômico-financeiros decorrentes do modelo, principalmente nas áreas de saúde e educação.

Não obstante a importância que os problemas orçamentários tem despertado, este trabalho se ocupará da questão político-jurídica. Para tanto, espera-se demonstrar a influência que o desenvolvimento cultural nacional pode ter representado nessa opção institucional ímpar. Como um estadunidense receberia a informação de que, no Brasil, o município é entidade federativa? Provavelmente, perguntando-se sobre a origem da opção políticojurídica, posto que desde o início daquela primeira federação sabem que se originou da união de Estados independentes. Trata-se, puramente, de uma criação constituinte, sem qualquer vinculação com a história e a cultura brasileira?

Vislumbrando importância para o desenvolvimento do Direito e da Ciência Política, a reflexão sobre a posição do município no arranjo institucional brasileiro não pode ser realizada sem auxilio da historiografia, que tanto tem se desenvolvido nessas últimas décadas. Nesse sentido, primeiro é necessário revisar o desenvolvimento político-jurídico do município na república brasileira, visando compreender o grau de autonomia e descentralização que se anuncia contemporaneamente. Na sequência, será necessário abordar a situação do tema durante o império, para aferir se há resquícios daquele tempo. Por fim, acredita-se que a análise dos poderes locais na época colonial possa contribuir para melhor compreensão da situação.

Ainda, espera-se motivar outros estudos que possam superar as deficiências decorrentes dos limites desta proposta, de modo que seja possível contribuir para o 
desenvolvimento do municipalismo e, no radical, para a própria cidadania. Afinal, os brasileiros não se agregaram - não houve Província independente! -, e sempre viveram nas villas, nas cidades, nos municípios: cada qual em seu lugar no mundo.

\section{O MUNICÍPIO NA REPÚBLICA FEDERATIVA BRASILEIRA}

A atual conformação constitucional do município brasileiro também é apontada como única do gênero por Paulo Bonavides: "Não conhecemos uma única forma de união federativa contemporânea onde o princípio da autonomia municipal tenha alcançado grau de caracterização política e jurídica tão alto e expressivo quando aquele que consta da definição constitucional do novo modelo implantado no país com a Carta de 1988.” (BONAVIDES, p. 276). A versão brasileira do federalismo foi destacada por Hely Lopes Meirelles:

De início, a Constituição da República de 1988, corrigindo falha das anteriores, integrou o Município na Federação como entidade de terceiro grau (arts. $1^{\circ}$ e 18), o que já reivindicávamos desde a $1^{\text {a }}$ edição desta obra [1957], por não se justificar a sua exclusão, já que sempre fora peça essencial da organização políticoadministrativa brasileira. (MEIRELLES, p. 42 et seq.) ${ }^{1}$.

Sustentando o equívoco do reconhecimento constitucional do Município como ente federativo de terceiro grau, gerador de uma federação "muito complexa, com entidades superpostas”, José Afonso da Silva reconhece que, nos termos da Constituição, o Município brasileiro tem a peculiaridade de integrar a federação como entidade político-administrativa dotada de autonomia política (capacidade de auto-organização e autogoverno), normativa (capacidade de fazer leis próprias sobre matéria de sua competência), administrativa (administração própria e organização dos serviços locais) e financeira (capacidade de

\footnotetext{
1 O autor justifica: "A característica fundamental da atual Carta é a ampliação da autonomia municipal, no tríplice aspecto político, administrativo e financeiro, conforme estabelecido nos arts. 29 a 31,156, 158 e 159, outorgando-lhe, inclusive o poder de elaborar a sua lei orgânica (Carta Própria), anteriormente adotada apenas pelo Estado do Rio Grande do Sul, desde a Lei Júlio de Castilhos, de 12.1.1897. Extinguiu, também, a nomeação de prefeitos para qualquer Município, manteve a eleição direta para vereadores (art. 29) e vedou a criação de Tribunais, Conselhos ou órgãos de contas municipais (art. 31, par. $4^{\circ}$ ). Observamos, ainda, que, além da competência privativa do Município para algumas matérias (art. 30), a nova Constituição deu-lhe competência comum com a União, os Estados e o Distrito Federal para outras que especifica em seu art. 23. E dentro de sua competência privativa está a de "legislar sobre assuntos de interesse local" (art. 30, I), em substituição à tradicional expressão "peculiar interesse", consagrada em todas as Constituições Republicanas anteriores, o que melhor definiu as atribuições privativas da Municipalidade. No que concerne aos tributos, a Constituição vigente ampliou a sua competência impositiva (art. 156) e aumentou a sua participação nos impostos partilhados (arts. 158 e 159 , par. $3^{\circ}$ ). (Ibidem).
} 
decretação de seus tributos e aplicação de suas rendas, que é uma característica da autoadministração) (SILVA, p. 450 et seq.) $)^{2}$.

José Nilo de Castro agrega as posições de Roque Antônio Carrazza e Raul Machado Horta para rejeitar o reconhecimento do município como unidade federativa porque: 1) não têm representação no Senado Federal; 2) não podem propor emendas à Constituição Federal; 3) não possuem Poder Judiciário; 4) não possuem Tribunais de Contas; e 5) suas leis ou atos normativos não se sujeitam ao controle concentrado do STF. Nada obstante, reconhece o ineditismo das "peculiaridades que circunscrevem" o ente brasileiro em relação àqueles das outras federações, agora com autonomia política: "É o Município entidade condômina de exercício de atribuições constitucionais. É dizer: possui o Município dignidade constitucional. É autônomo na Carta Magna de hoje quanto na anterior e anteriores, desde 1934. Falecia-lhe apenas auto-organização." (CASTRO, p. 55).

Apesar das divergências acerca da aceitação dos municípios como entes federativos que não afeta o objeto deste estudo - não se vislumbra divergência doutrinária acerca da autonomia municipal, no sentido de prerrogativa política estabelecida e limitada pelo constituinte $^{3}$. Assim Michel Temer sustenta que a autonomia municipal "vem assegurada no art. 18 e disciplinada nos arts. 29 e 30 de sua Lei Fundamental de 1988, e representa a capacidade de auto-organização, autogoverno, autolegislação e auto-administração, caracterizando a autonomia política, normativa, administrativa e financeira." (TEMER, p. 58, et seq.).

A autonomia municipal, que já estava garantida já na primeira Constituição da república ${ }^{4}$, só se consolidou após a Constituição de $1946^{5}$ - depois de ensaiada pela Carta de $1934^{6}$, que logo restou afetada pelo intervencionismo instalado em $1937^{7}$.

\footnotetext{
2 Não obstante, questiona: Com isso, a Federação brasileira adquire peculiaridade, configurando-se, nela, realmente três esferas governamentais: a da União (governo federal), a dos Estados Federados (governos estaduais) e a dos Municípios (governos municipais), além do Distrito Federal, a que a Constituição agora conferiu autonomia. E os municípios transformaram-se mesmo em unidades federadas? A Constituição não diz. Ao contrário, existem onze ocorrências das expressões unidade federada e unidade da Federação (no singular ou no plural) referindo-se apenas aos Estados e Distrito Federal, nunca evolvendo os Municípios. (Idem, p. 590).

3 Meirelles destaca: "Autonomia é prerrogativa política outorgada pela Constituição a entidades estatais internas (Estados-membros e Municípios), para compor o seu governo e prover a sua Administração segundo o ordenamento jurídico vigente (CF, art. 18). É a administração própria daquilo que lhe é próprio. Daí por que a Constituição assegura a autonomia do Município pela composição de seu governo e pela administração própria no que concerne ao seu interesse local (art. 30, I)." (Idem, p. 80).

4 Constituição da República dos Estados Unidos do Brasil de 1891: “Art 68 - Os Estados organizar-se-ão de forma que fique assegurada a autonomia dos Municípios em tudo quanto respeite ao seu peculiar interesse." Contudo, Meirelles ressalva: "Durante os 40 anos em que vigorou a Constituição de 1891 não houve autonomia municipal no Brasil. O hábito do centralismo, a opressão do coronelismo e a incultura do povo transformaram os Municípios em feudos políticos e truculentos, que mandavam e desmandavam nos "seus" distritos de influência, como se o Município fosse propriedade particular e o eleitorado um rebanho dócil ao seu poder. Os prefeitos eram eleitos ou nomeados ao sabor do governo estadual, representado pelo "chefe"todo-poderoso da "zona". As eleições eram de antemão preparadas, arranjadas, falseadas ao desejo do "coronel". As oposições que se esboçavam no interior viam-se aniquiladas pela violência e pela perseguição política do situacionismo local e estadual. Não havia qualquer garantia democrática. E, nessa atmosfera de opressão, ignorância e mandonismo, o Município viveu quatro décadas, sem recurso, sem liberdade, sem progresso, sem autonomia. Tal situação foi magistralmente focalizada por Nunes Leal em obra que traduz fielmente a política municipalista brasileira até 1946." (MEIRELLES, p. 12 et seq.).
} 
A Constituição de 1967, dedicada ao centralismo e ao privilégio do Executivo, manteve a autonomia municipal, e a Emenda Constitucional de 1969 afetou a escolha de Prefeitos nas Capitais, estâncias hidrominerais e áreas de segurança nacional ${ }^{8}$.

Para José Nilo de Castro essa autonomia é sustentada pela descentralização relativa ${ }^{9}$, interessando para este estudo essa relação entre autonomia e descentralização, afirmada na seguinte passagem:

A autonomia pressupõe aptidão para se governar livremente, poder de se fazer as leis e capacidade de se determinar órgãos de representação. O sentido jurídico da autonomia, aqui, a que provém do fenômeno descentralização, resume-se não apenas na assunção de gestão dos interesses locais, no plano administrativo, mas, sobretudo, no plano político. Em sendo hoje o Município, que antecedera ao Estado como poder público, criatura do Estado, uma instituição jurídica em que se consolidaram hábitos democráticos e que se define como caixa de ressonância dos poderes políticos e da democracia, produto da descentralização política, não se encontra explicação legítima alguma que descaracterize esse entendimento. (CASTRO, p. 46 et seq.).

Esse fenômeno jurídico-político típico da redemocratização pós-1988 se disseminou de forma marcante na legislação infraconstitucional, seguindo o modelo constitucional da política urbana e dos sistemas únicos de saúde e assistência social ${ }^{10}$.

5 Conforme Meirelles: "Dentro desse esquema, ficou assegurada a autonomia política, administrativa e financeira: (...)" (Idem, p. 34).

6 Castro destaca: “A Constituição de 16 de julho de 1934 foi inovadora na organização municipal, pois propiciou o afastamento do mandonismo político dos Estados que, no regime anterior, pelas Constituições e por sua Leis de Organização Municipal, oprimiam os Municípios." (CASTRO, p. 41)

7 Meirelles é enfático: "Pode-se afirmar, sem vislumbre de erro, que, no regime de 1937, as Municipalidades foram menos autônomas que sob o centralismo imperial, porque, na Monarquia, os interesses locais eram debatidos nas Câmaras de Vereadores e levados ao conhecimento dos governadores (Lei de 1828) ou das Assembléias Legislativas das Províncias (Ato Adicional de 1834), que proviam a respeito, ao passo que, no

sistema interventorial do Estado Novo, não havia qualquer respiradouro para as manifestações locais em prol do

Município, visto que os prefeitos nomeados governavam discricionariamente, sem a colaboração de qualquer órgão local de representação popular." (MEIRELLES, p. 33 et seq.).

8 Art. 15. A autonomia municipal será assegurada: $\$ 1^{\circ}$ Serão nomeados pelo Governador, com prévia aprovação: a) da Assembléia Legislativa, os Prefeitos das Capitais dos Estados e dos Municípios considerados estâncias hidrominerais em lei estadual; e b) do Presidente da República, os Prefeitos dos Municípios declarados de interêsse da segurança nacional por lei de iniciativa do Poder Executivo.

9 O autor esclarece: "Compreendendo a descentralização a personalidade jurídica da coletividade de habitantes, o jus imperii atribuído a esta coletividade, patrimônio a ela afetado e órgãos de representação, tem-se na percepção de sua noção relativa a configuração de seus elementos constitutivos, a saber: os interesses locais, as autoridades locais e o controle do poder central. À sua base está, indiscutivelmente, a autonomia e sua noção como categoria jurídica.” (CASTRO, p. 46).

10

10 Destaca-se da Constituição Federal de 1988: Art. 182. A política de desenvolvimento urbano, executada pelo Poder Público municipal, conforme diretrizes gerais fixadas em lei, tem por objetivo ordenar o pleno desenvolvimento das funções sociais da cidade e garantir o bemestar de seus habitantes. $\S 1^{\circ}$ - O plano diretor, aprovado pela Câmara Municipal, obrigatório para cidades com mais de vinte mil habitantes, é o instrumento da política de desenvolvimento e de expansão urbana. Art. 198. As ações e serviços públicos de saúde integram uma rede regionalizada e hierarquizada e constituem um sistema único, organizado de acordo com as seguintes diretrizes: I - descentralização, com direção única em cada esfera de governo; (...) Art. 204, da Constituição de 1988. As ações governamentais na área da assistência social serão realizadas com recursos do orçamento da seguridade social, previstos no art. 195, além de outras fontes, e organizadas com base nas seguintes diretrizes: I - descentralização político-administrativa, cabendo a coordenação e as normas gerais à esfera federal e a coordenação e a execução dos respectivos programas às esferas estadual e municipal, bem como a entidades beneficentes e de assistência social; (...) 
Nesse sentido, destaca-se a municipalização da política de atendimento dos direitos da criança e do adolescente ${ }^{11}$ e do Sistema Único de Saúde ${ }^{12}$; a organização da assistência social $^{13}$, e o estabelecimento das diretrizes e bases da educação nacional ${ }^{14}$.

A festejada conformação do município brasileiro contemporâneo, modelo de autonomia ímpar e ícone da descentralização federativa, não foi forjada apenas na doutrina jurídica ou na constituinte de 1998, como se vislumbra na superfície daquilo que até agora se analisou - ressalvada a amplitude restrita e os objetivos desse estudo.

Há contextos fáticos ocultos que merecem a análise de contrapelo proposta pela historiografia francesa de Annales, conforme adverte Luís Fernando Lopes Pereira:

É preciso também se livrar do acontecimento, armadura antinatural e artificial, mera "espuma no mar da história" de acordo com Fernand Braudel, para buscar os valores duradouros, as estruturas de longa duração, onde o direito se manifesta através de um universo de signos que emergem de valores históricos, em um modelo mental próprio que Paolo Grossi denomina "mentalidade jurídica", afinal, "cada instituto jurídico é signo de uma escolha produzida no nível do costume jurídico que tem um fundamento antropológico e corresponde a uma visão que uma civilização histórica tem das relações entre homem, sociedade e natureza”. Assim é possível resgatar o direito escrito na história, onde os valores jurídicos são escolhas locais, embora a nossa se esconda por detrás de um tecnicismo burocrático. A construção do direito é feita a partir de respostas específicas do mundo jurídico às demandas das comunidades, o que o torna plural e complexo e exige seu acolhimento e não sua obediência forçada. ${ }^{15}$ (PEREIRA, 2006, 134 et seq.)

11 Destaca-se da Lei $\mathrm{n}^{\circ}$ 8.069, de 13 de julho de 1990: Art. 88. São diretrizes da política de atendimento: I - municipalização do atendimento; Art. 100. Na aplicação das medidas levar-se-ão em conta as necessidades

pedagógicas, preferindo-se aquelas que visem ao fortalecimento dos vínculos familiares e comunitários. (...) III -

responsabilidade primária e solidária do poder público: a plena efetivação dos direitos assegurados a crianças e a adolescentes por esta Lei e pela Constituição Federal, salvo nos casos por esta expressamente ressalvados, é de responsabilidade primária e solidária das 3 (três) esferas de governo, sem prejuízo da municipalização do atendimento e da possibilidade da execução de programas por entidades não governamentais;

Destaca-se da Lei $n^{\circ}$ 8.080, de 19 de setembro de 1990: Art. $7^{\circ}$ As ações e serviços públicos de saúde e os serviços privados contratados ou conveniados que integram o Sistema Único de Saúde (SUS), são desenvolvidos de acordo com as diretrizes previstas no art. 198 da Constituição Federal, obedecendo ainda aos seguintes princípios: (...) IX - descentralização político-administrativa, com direção única em cada esfera de governo: a) ênfase na descentralização dos serviços para os municípios; (...) Art. 16. A direção nacional do Sistema Único da Saúde (SUS) compete: (...) XV - promover a descentralização para as Unidades Federadas e para os Municípios, dos serviços e ações de saúde, respectivamente, de abrangência estadual e municipal; (...) Art. 17. À direção estadual do Sistema Único de Saúde (SUS) compete: I - promover a descentralização para os Municípios dos serviços e das ações de saúde; (...)

3 Destaca-se da Lei $n^{\circ}$ 8.742, de 07 de dezembro de 1993: Art. $5^{\circ}$ A organização da assistência social tem como base as seguintes diretrizes: I - descentralização político-administrativa para os Estados, o Distrito Federal e os Municípios, e comando único das ações em cada esfera de governo; Art. 18. Compete ao Conselho Nacional de Assistência Social: (...) V - zelar pela efetivação do sistema descentralizado e participativo de assistência social;

14 Destaca-se da Lei n 9.394, de 20 de dezembro de 1996: Art. 11. Os Municípios incumbir-se-ão de: (...) V - oferecer a educação infantil em creches e pré-escolas, e, com prioridade, o ensino fundamental, permitida a atuação em outros níveis de ensino somente quando estiverem atendidas plenamente as necessidades de sua área de competência e com recursos acima dos percentuais mínimos vinculados pela Constituição Federal à manutenção e desenvolvimento do ensino.

15 E mais: “As raízes do jurídico são encontradas também nas mentalidades, nas bases profundas que expressam os valores sociais, ligados ao modo particular de sentir, viver e conceber o direito que é uma mentalidade afundada na consciência social, ou nas palavras de Paolo Grossi, "um complexo de valores circulantes em uma área espacial e temporal capaz, pela sua vitalidade, de superar a diáspora de fatos e episódios e de constituir o tecido conectivo escondido e constante daquela área". Só a partir de análises assim poderemos fazer explodir o contínuo da história, resgatar os mortos e impedir uma nova vitória dos vencedores, interrompendo a sucessão de ruínas que o anjo da história, atingido por uma espécie de incapacidade ou deformação, já não suporta ver e assim interromper o curso nefasto do tempo e empreender a obra salvadora da memória, livrando-se de um presente pervertido que não passa da repetição do idêntico e fazendo história com arte." (Idem, p. 136). 
A partir desse recorte metodológico se justifica perquirir se (e quanto) o atual estado de descentralização republicana, e consequente autonomia municipal, pode ser considerado permanência do modelo imperial.

\section{VILLAS E CIDADES NO IMPÉRIO BRASILEIRO}

Preliminarmente, cabe registrar que a expressão "município" só veio grafada nas constituições republicanas. Na Constituição Imperial de 1824 a referência "municipaes" estava ligada às funções de governo atribuídas às Câmaras das villas e cidades ${ }^{16}$. José Nilo de Castro alerta sobre as distinções que devem ser consideradas:

Como se sabe, no Direito Municipal de hoje, cidade e vila têm significado e conformação jurídicos diversos. Cidade: sede do Município, que lhe dá o nome; vila: a sede do Distrito, que lhe dá o nome. No Império, a diferença entre a cidade e a vila identificava-se apenas pelo critério democrático e pela composição dos membros das Câmaras Municipais. É que as Câmaras das cidades eram compostas de nove membros, além do secretário, e as das vilas, de sete. (CASTRO, p. 38).

A afetação da autonomia municipal no início da república, se verá, é permanência do centralismo e do elitismo (coronelismo) que se agigantaram no período imperial.

Antes, importa lembrar que a independência brasileira foi impulsionada pelo retorno de D. João VI a Portugal em fevereiro de 1821, premido pela crise que assolava o reino e pela Revolução Liberal (ou Constitucionalista) do Porto ${ }^{17}$.

Um ano depois, o Príncipe Regente Pedro I resistiu à pressão metropolitana e optou por ficar (09 de janeiro de 1822), proclamando a independência no mesmo ano. Em 1824, e patrocinando fracasso da assembléia constituinte "da mandioca" 18 , outorgou a Carta Imperial.

\footnotetext{
16 Os artigos 167 a 169, da Constituição Política do Império do Brazil, tratavam das "Das Camaras", no Título "Da Administração e Economia das Províncias".

17 Nesse sentido o registro da lembrança de D. Pedro I: "Eu ainda me lembro e me lembrarei sempre do que Vossa Majestade me disse antes de partir dois dias, no seu quarto: Pedro, se o Brasil se separar, antes seja para ti, que me hás de respeitar do que para algum dêsses aventureiros." (SOUSA, 1972, p. 227).

18 Denominação decorrente das condições de capacidade eleitoral que estavam previstas no anteprojeto.
} 
Abalado pela pressão das elites - decorrência dos problemas econômicos e também políticos, desde a constituinte -, pelo fracasso da campanha cisplatina e pelo assédio restaurativo de Portugal - para não falar dos problemas pessoais -, Pedro I abdicou em 1831, em favor do filho (então com cinco anos de idade). A situação motivou a instalação período regencial, que durou até a antecipação da maioridade de Pedro II, em 1840.

Desde a Confederação do Equador (1824), a oposição ao centralismo imperial motivou vários movimentos liberais revolucionários. A leitura de José Afonso da Silva revela o quanto esses eventos do período imperial foram motivados pela afetação da autonomia local e em favor da descentralização:

Os liberais lutaram quase sessenta anos contra esse mecanismo centralizador e sufocador das autonomias regionais. A realidade dos poderes locais, sedimentada durante a colônia, ainda permanecia regurgitante sob o peso da monarquia centralizante. A idéia descentralizadora, como a republicana, despontara desde cedo na história político constitucional do Império. Os federalistas surgem no âmago da Constituinte de 1823, e permanecem durante todo o Império, provocando rebeliões como as "Balaiadas", as "Cabanadas", as "Sabinadas", a "República do Piratini". Tenta-se implantar, por várias vezes, a monarquia federalista do Brasil, mediante processo constitucional $(1823,1831)$, e chega-se a razoável descentralização com o ato Adicional de 1834, esvaziado pela lei de interpretação de 1840. (SILVA, p. 78).

Hely Lopes Meirelles lembra que o governo municipal atribuído às Câmaras dependia de regulamentação ${ }^{19}$, que só veio em 1828 , e de tal forma que subordinou os poderes locais às Províncias, frustrando totalmente a autonomia prometida na Constituição. A tentativa de descentralização veiculada pelo Ato Adicional de 1834 também restou malfadada, tanto que demandou uma Lei de interpretação em 1840 que, contudo, não foi suficiente, tanto que não havia prefeitos, mas apenas delegados do Executivo nomeados pelos Presidentes das Províncias.

\footnotetext{
${ }^{19}$ O artigo 169, da Constituição Imperial estabelecia: "O exercicio de suas funcções municipaes, for mação das suas Posturas policiaes, applicação das suas rendas, e todas as suas particulares, e uteis attribuições, serão decretadas por uma Lei regulamentar."
} 
O centralismo provincial não confiava nas administrações locais e poucos foram os atos de autonomia praticados pelas Municipalidades, que, distantes do poder central, e desajustadas pelo governo da Província, minguavam no seu isolamento, enquanto os presidentes provinciais cortejavam o Imperador, e o Imperador desprestigiava os governos regionais, na ânsia centralizadora que impopularizava o Império. Na vigência da Lei regulamentar de 1828, que perdurou até a República, as Municipalidades não passaram de uma divisão territorial, sem influência política e sem autonomia na gestão de seus interesses, ante a expressa declaração daquele diploma legal de que as Câmaras eram corporações meramente administrativas (art. 24). Desprestigiadas politicamente, as Municipalidades do Império contrastaram gritantemente com a organização anterior, do Município colonial, que desfrutava de franquias mais largas e consentâneas com suas finalidades. (MEIRELLES, p. 30).

Para Levy Carneiro "a Lei 28 organizou os governos municipais, com o mesmo sentido centralizador, a mesma suspeita contra o espírito local - até certo ponto compreensível, porque este espírito dominara a vida dispersa, desconexa, do período colonial" (CASTRO, p. 39 et seq.), seguindo a orientação da Constituição Imperial.

Para além da centralização do poder nas Assembléias Provinciais, Themistocles Cavalcanti registra que o Visconde do Uruguai já observava o fato do ato adicional ter sido "hostil ao elemento municipal, e que foram os autores do ato adicional que maiores feridas fizeram na autonomia municipal." (CAVALCANTI, p. 200).

Concordando que o Ato Adicional de 1834 "reduziu as municipalidades a meras executoras das deliberações das assembléias provinciais e dos presidentes das Províncias, agentes do Poder Central", José Nilo de Castro também não encontrou atenuação na Lei Interpretativa de 1840, situação que aniquilou o municipalismo no período imperial:

Tira-se do sentido e das competências das Províncias que o Brasil, no Império, não chegou a ter governo municipal autônomo, pois que toda a evolução política e jurídica, na questão, direcionou-se para as Províncias. Tem-se explicação para tanto: o Brasil, Estado Imperial Unitário, a força centrípeta que o Imperador personificava nas Cortes, impedia qualquer sopro prático de descentralização. Daí porque episódios esporádicos, aqui e ali, assinalando investidas municipais e descentralizadoras, não desfiguraram, até a República, a fisionomia centralizadora do Império, com sacrifícios para as liberdades locais, como acontecera com o Município romano, sob o centralismo de Constantino. É que, aqui como alhures, o prestigiar-se os Municípios significava desfazer-se do poder das Províncias, cuja autonomia era desconsolo das Câmaras Municipais. (CASTRO, p. 40). 
Antonio Carlos Otoni Soares amplifica a constatação de Helly Lopes Meirelles, sobre a permanência dos efeitos desse período de tutela imperial no municipalismo republicano:

Toda tradição lusobrasileira de agressiva rusticidade das Câmaras Municipais, de defesa intransigente dos direitos da comunidade local ao exercício do auto-governo, passa a ser esquecido com o regime da tutela, na verdade um autêntico programa nacional de inibição das potencialidades municipais, do espírito de iniciativa, enfim, das tendências espontâneas do povo brasileiro ao autogoverno. Suas maléficas consequiências repercutem até os dias de hoje. O regime da tutela estatal sobre os municípios, importado da França, provocou no povo brasileiro, nas populações do interior, uma apatia desastrosa, semelhante a de grupos primitivos apáticos que não sabem o que querem nem para onde ir. Foi, sem dúvida alguma, uma grande vitória das elites do Império, abater o moral de populações municipais que, dirigidas por suas Câmaras de Vereadores, participavam ativamente da revolução pela Independência do Brasil. (SOARES, p. 10).

António Manuel Hespanha registra que os primeiros constituintes portugueses discutiram o projeto de um poder regional (quarto poder) para as Províncias - que só existiam no Brasil e em Portugal -, visando acomodar as aspirações autonomistas dos brasileiros. Tal idéia não vingou porque o pensamento revolucionário não concebia atividade administrativa desvinculada da lei, isto é, autônoma e discricionária. "Do ponto de vista institucional, essa antiga liberdade das Câmaras era justamente um dos entraves, que se queria evitar, à soberania nacional. Do ponto de vista conjuntural, qualquer autonomia dada ao governo local queria dizer favorecer o federalismo ou a secessão brasileira.” (HESPANHA, 2004, p. 104).

Em razão disso as Províncias não ganharam contornos político-administrativo, enquanto o governo econômico e municipal dos Concelhos (denominação para municípios) permaneceu atribuído às Câmaras, no Título "Do Governo administrativo e econômico"20". Para Hespanha, a limitação constitucional do poder das câmaras era apenas teórico:

Em suma. Realmente, algo de muito parecido com um quarto poder existia na Constituição de 1822. Não ao nível, politicamente visível, de uma descentralização "federal". Mas ao nível discreto de uma larga autonomia distrital e concelhia. A primeira consubstanciada no carácter decisório de mini-parlamentos regionais, apoiados na autoridade executiva de um alto magistrado, nomeado diretamente pelo rei, com audição do Conselho de Estado. Mas, na prática, mais decisiva era ainda a autonomia municipal, pelas atribuições constitucionais que lhe correspondem mas, sobretudo, pela carga tradicional que lhe subjazia. (HESPANHA, 2004, p. 105).

\footnotetext{
${ }^{20}$ Conforme artigos 218 a 223, da Constituição Portuguesa de 1822.
} 
Logo, a centralização e a atrofia do município promovidas pelo Imperador Pedro I não é permanência do projeto português.

Não obstante, e quando o país já era governado pelo sistema de regências justamente na transição da regência trina permanente ${ }^{21}$ para a regência una ${ }^{22}$, em 1834 - o falado Ato Adicional de 1834 aplicou a capis diminutio vivenciada pelo municipalismo até a metade do século $\mathrm{XX}^{23}$.

Ora, se não é resquício reinol e não se concretizou pelo empenho imperial, o legado centralista só poder ser produto do empenho elitista, conforme afirmado. José Murilo de Carvalho observa essa centralização quando compara os processos de independência das colônias espanholas e portuguesas, e atribuiu a unidade nacional ao processo de formação dessas elites desde o período colonial:

\begin{abstract}
Argumentaremos, portanto, que a adoção de uma solução monárquica no Brasil, a manutenção da unidade da ex-colônia e a construção de um governo civil estável foram em boa parte consequiência do tipo de elite política existente à época da Independência, gerado pela política colonial portuguesa. Essa elite se caracterizava sobretudo pela homogeneidade ideológica e de treinamento. Havia sem dúvida certa homogeneidade social no sentido de que parte substancial da elite era recrutada entre os setores sociais dominantes. Mas quanto a isto não haveria muita diferença entre o Brasil e os outros países. (...) A homogeneidade ideológica e de treinamento é que iria reduzir os conflitos intra-elite e fornecer a concepção e a capacidade de implementar determinado modelo de dominação política. (CARVALHO, p. 21).
\end{abstract}

Do exposto, conclui-se que o modelo descentralizado e autônomo exposto na primeira seção não é resquício do período imperial quando, do contrário, a autonomia municipal foi afetada sobremaneira pelas elites brasileiras. Resta perquirir se, então, tais características podem ser herança cultural (permanência!) do período colonial.

\title{
3 VILLAS E CIDADES NO BRASIL COLONIAL. ${ }^{24}$
}

Considerando que nem o período imperial brasileiro utilizou a terminologia município (como já anotado na seção anterior), as villas e cidades das quais se tem notícia são

\footnotetext{
21 A Regência Trina Permanente dos Deputados José da Costa Carvalho (Marquês de Monte Alegre) e João Bráulio Moniz, e do senador Francisco de Lima e Silva administrou o império de junho de 1831 até abril de 1835.

22 Foram Regentes Unos Diogo Feijó (1835-1837) e Araújo Lima (1837 até a posse de D. Pedro II).

23 Desconsiderando-se o curto período de vigência da Constituição de 1934.

24 O termo "colonial" é utilizado no sentido cronológico, conforme sugerido por VAINFAS (p.83).
} 
aquelas que os portugueses organizaram conforme o modelo que trouxeram d'além mar.

Diversamente dos espanhóis que colonizaram territórios de maias, incas e astecas, onde se destacam "cidades" como Uxmal, Chichén-Itza, Tikal, Chapultepec, Tenochtitlán e Cuzco, não há estudos que permitam traçar paralelos entre os hábitos de vida dos nativos que viviam no Brasil na época da chegada dos colonizadores.

Registrando a fundação da vila de São Vicente (em 1532), José Nilo de Castro sustenta que "o município precedeu o próprio Estado, no Brasil, daí ser o fundamento de nossa nação." (CASTRO, p. 36). Há mais anacronismos nessa leitura:

Outros Municípios seguem-se: Olinda, 1537; Santos, 1545; Salvador, 1549; Santo André da Borda do Campo, 1553; Rio de Janeiro, 1567. Às Câmaras se reconheciam molduras republicanas. Eram conhecidas como Repúblicas, e os Vereadores, repúblicos ou republicanos. Daí os termos: Senadores das Câmaras Municipais do Brasil. (CASTRO, p. 37).

Nem Hely Lopes Meirelles ajuda na compreensão dessa fase, embora não tão anacrônico:

\begin{abstract}
No período colonial, a expansão municipalista foi restringida pela idéia centralizadora das Capitanias, afogando as aspirações autonômicas dos povoados que se fundavam e se desenvolviam mais pelo amparo da Igreja que pelo apoio dos donatários. Mesmo assim, as Municipalidades de então tiveram inegável influência na organização política que se ensaiava no Brasil, arrogando-se, por iniciativa própria, relevantes atribuições de governo, de administração e de justiça. (MEIRELLES, p. 28, et seq.).
\end{abstract}

Vislumbra-se que a dificuldade dos especialistas em Direito Municipal resida nas fontes desse período que, para além de escassas, ainda estão a merecer atenção adequada ${ }^{25}$, como alerta Laura de Mello e Souza:

Durante muito tempo, o estudo da administração portuguesa no Brasil dos tempos coloniais foi relegado a um segundo plano pouco honroso. (...) Para os brasileiros, inclusive alguns de minha geração, a administração era tema sem nobreza nenhuma, bem ao gosto de historiadores afeitos à tradição e ao conservadorismo,(...)." (SOUZA, p. 27).

\footnotetext{
25 Hespanha destaca esses aspectos da situação portuguesa: "Este desinteresse dos historiadores pelo município moderno explica-se, decerto, pelo discurso - por vezes ideologicamente muito marcado - da decadência das instituições concelhias a partir do séc. XV (sobre o quel, v. a "Introdução"). Mas explica-se também, como diremos num capítulo ulterior, ao tratar da administração não formal pelo estado das fontes. De facto, o mundo local - sobretudo o mundo dos pequenos concelhos - quase não deixou vestígios escritos. Frequentemente, a técnica de registro escrito não estava sequer aí suficientemente estabelecida, e, de qualquer modo, a remodelação profunda do mapa dos concelhos depois de 1832, com a extinção de centena deles, dispersou e fez perder a generalidade dos seus arquivos. Por outro lado, se recorrermos à tradição literária (dos juristas e dos repúblicos), raro é que aí encontremos uma imagem fiel deste mundo. Na verdade, ou ele é pura e simplesmente silenciado ou é subsumido ao modelo da administração concelhia das cidades principais."
} 
Nesse recorte crítico segue Laura de Mello e Souza registrando que, embora Raymundo Faoro tenha fornecido alternativa analítica para compreensão das elites brasileiras $^{26}$, exagerou na exposição do papel do Estado ao disseminar a idéia "perigosa" de que antecedeu a sociedade porque a organização administrativa (vilas/cidades) se criava antes do afluxo das populações, como sendo possível a realidade ser gerada pela lei: “O papel da dinâmica social e das contradições viu-se, assim, minimizado: não houve lugar, em sua análise para as tensas e complexas relações entre administradores coloniais e as oligarquias, amiúde documentadas nas fontes coevas." (SOUZA, p. 31). Para além disso, o ensaio explicativo de Faoro busca um enquadramento geral com enfoques particularizados que contradizem as explicações propostas (SOUZA, p. 40).

No mesmo contexto, alerta para os anacronismos de Caio Prado $\mathrm{Jr}^{27}$ e para as comparações inadequadas de Sérgio Buarque de Holanda com a colonização espanhola na América $^{28}$. "O exame destes três autores mostra, portanto, que o melhor do ensaísmo brasileiro nos anos 1930, 1940 ou 1950 ajudou a afirmar uma visão negativa da administração portuguesa na América." (SOUZA, p. 40). Por fim destaca a sensibilidade de Stuart Schwartz ${ }^{29}$, que reconheceu Gilberto Freyre como o único a ter uma visão otimista desse período primordial do país, fato que lhe rendeu críticas sobre a positividade da miscigenação.

Considerando que "os pressupostos teóricos abraçados por Antonio Manuel Hespanha funcionam bem no estudo do seiscentos português" (SOUZA, p. 40), opta-se por este referencial para a análise do período colonial.

Resgatando o direito de autonomia do governo das comunidades territoriais na Antiguidade e no direito natural, Hespanha afirma que a capacidade de governar-se "a si

\footnotetext{
26 Referindo-se ao primeiro volume de Os donos do poder : formação do patronato político brasileiro. $2^{\mathrm{a}}$ ed., Porto Alegre/São Paulo: Edusp, 1975 .

Referindo-se ao Formação do Brasil contemporâneo. 13a ed., São Paulo: Brasiliense, 1973. A análise da tripartição dos poderes no antigo regime se assemelha aos anacronismos destacados na obra de José Nilo de Castro.

28 Referindo-se ao Raízes do Brasil. 9a ed., Rio de Janeiro: José Olympio, 1976. Nesse sentido observa Ronaldo Vainfas: "Sérgio Buarque realizou uma comparação entre as cidades portuguesas e espanholas, destacando a intensa vida urbana da América Espanhola em contraste com a Portuguesa. Desde o início da colonização, a cidade hispano-americana teria sido concebida como corte, local apropriado para o encontro de espanhóis

abastados com o intuito de preservar as tradições ibéricas, como na Cidade do México ou em Lima. Os núcleos urbanos eram planejados, oriundos do interesse em ordenar e dominar o mundo conquistado. Nas cidades da América Portuguesa, pelo contrário, não haveria o mesmo ânimo ordenador. Tudo aqui seria sem rigor ou método, imperando certo desleixo evidenciado pela falta de traçados geométricos e por ruas que acompanhavam as ondulações e variações do terreno." (VAINFAS, p. 118 et seq.)

29 Refere-se à entrevista "O país do presente", publicada na Veja, no 1594, de 21 de abril de 1999.
} 
mesmo (jurisdictio) e de editar as suas normas jurídicas próprias (iura propria, direitos próprios; statuta, estatutos) era geralmente atribuída a qualquer comunidade humana com identidade territorial própria, desde a aldeia ao reino (aldeia, cidades, comarca, província).” E distingue:

Pagus ou villa é a povoação onde não há nem governo nem tribunal próprio, ou seja, o agregado desprovido de autonomia jurisdicional. Quando muito, pode existir algum magistrado ou oficial, com poderes delegados pelos magistrados da circunscrição político-administrativa em que se insere. Em Portugal, aldeias eram os "casais", "lugares" ou, mesmo, as freguesias (que apenas tinham organização político-administrativa eclesiástica). No entanto, as Ordenações (Ord. Fil., I, 65, 73/4) previam a existência de juízes vintaneiros ou pedâneos, delegados dos juízes ordinários do concelho, em aldeias maiores, com atribuições judiciais sobre as causas de pouco valor. A cidade é a circunscrição com autonomia de governo. O direito conhecia uma gradação entre elas, consoante o âmbito dessa autonomia. Na época moderna, o título de cidade era atribuído apenas a certos aglomerados urbanos dotados de certa grandeza, definida por diversos critérios, dos quais se destacava o ser sede de bispado. Em termos mais gerais, porém, cidade era qualquer povoação com jurisdição separada, ou seja, com autonomia de governo e jurisdição; a que correspondia, no plano institucional, um órgão de governo colectivo (em Portugal, uma câmara e juízes). Logo, o que a doutrina jurídica diz, em geral, para as civitates, aplica-se, entre nós, aos conselhos. (HESPANHA, 2006, p. 278).

Ronaldo Vainfas afirma que, embora o quadro geral do meio urbano colonial lusobrasileiro correspondesse ao exposto por Sérgio Buarque de Holanda ${ }^{30}$, pesquisas posteriores a 1980 encontram evidências de que havia engenheiros militares participando da edificação das cidades, sobretudo após o século XVII, e inclusive na Amazônia - no século XVIII:

\begin{abstract}
A historiografia tem procurado explorar novas perspectivas da cidade colonial. Se é verdade que, no conjunto, as vilas e cidades desempenharam papel secundário na economia colonial, foram muito importantes em outras esferas da sociedade. As funções políticas e religiosas presentes nas cidades nos permitem compreender a colônia não somente em relação ao mundo rural e à dimensão econômica da colonização. A cidade colonial fornece subsídios para a construção de um passado que não se reduz à dicotomia entre senhores e escravos, entre a casa-grande e a senzala, pois ilumina o cotidiano de outros segmentos sociais, homens livres pobres, libertos, vadios. Era nelas, enfim, que o poder dos potentados rurais tinha que se defrontar com a Igreja e os funcionários del rei. (VAINFAS, p. 120).
\end{abstract}

Silvia Hunold Lara confirma essa tendência de valorização da vida urbana nos estudos das últimas décadas, "sobretudo de arquitetos e urbanistas" que tem despertado o

\footnotetext{
${ }^{30}$ Vide nota 28.
} 
olhar para "o quanto tal política urbanizadora esteve a serviço dos interesses administrativos do governo metropolitano.” (LARA, p. 33). E reforça a afirmação de Vainfas:

A renovação trazida por esses estudos fez reacender o interesse pela vida urbana, sobretudo em relação aos aspectos administrativos e políticos das cidades nas áreas coloniais. Como resultado desses desdobramentos historiográficos, hoje é possível compreender as vilas e cidades coloniais como espaços físicos que não apenas "abrigavam" poderes políticos, econômicos, religiosos e militares do Estado português, mas que eram entranhados por eles e também pela atuação dos potentados locais. (...) Nesse contexto, as vilas e cidades das áreas coloniais constituíam um lugar em que vários tipos de dominação se articulavam. De um lado estava o poder régio, que se expunha e encontrava seus interlocutores mais diretos, das instituições da administração e do governo às autoridades e membros do corpo político. Associando-se aos funcionários régios, a nobreza da terra e as famílias de fortuna também se mostravam, concorrendo entre si pelos privilégios reais, mas se esforçando igualmente por afirmar, cada qual, seus privilégios e direitos locais. (LARA, p. 35; p. 76)

No plano político-jurídico, Hespanha destaca as posturas, o costume local, a atividade jurisdicional dos concelhos e o provimento dos ofícios das câmaras como pontos que caracterizaram a autonomia municipal dos seiscentos - ainda que afetada pelo domínio da elite econômica ${ }^{31}$. Essa ideia de "mundo local” interessava à coroa portuguesa:

Nestas condições, o domínio da periferia pelo centro só podia efectuar-se através de um sistema político que, deixando intocadas as estruturas políticas, jurídicas e culturais locais, se contentasse com uma sua integração penas epidérmicas no sistema político global, mas que bastasse para a consecução dos objetivos (nomeadamente fiscais simbólicos do poder central). (HESPANHA, 1994, p. 380).

Avanete Pereira Sousa também ressalta que a autonomia camarária não significava autogoverno $^{32}$ : “A autonomia de ação identificada dava-se no interior do sistema e não divergia dos ditames monárquicos. Ao contrário, a Câmara atuava de forma a fazer que as

31 Analisando a situação de Salvador, Avanete Pereira Sousa destaca: "Esses grupos, formados de pessoas identificadas como principais da terra, monopolizavam as instituições políticas locais, conformando uma elite camarária que, rotativamente, ocupava o conjunto dos cargos públicos municipais, criando barreiras ao acesso de outros segmentos sociais ao poder decisório sobre a coisa pública." (SOUSA, 2007, p. 319). Arno e Maria José Wehling vão além, e destacam a atuação das elites como limitação de fato ao poder do juiz ordinário: "O mandonismo rural elaborava suas próprias regras jurídicas, empíricas e violentas, subtraindo da apreciação da magistratura local casos de opressão e abuso de poder ou impondo seus interesses a magistrados intimidados pela presença muitas vezes tirânica do capitão-mor da vila.” (WEHLING, p. 69).

32 Arno e Maria José Wehling ressaltam: "Parece-nos que o direito que se produzia no âmbito municipal, tanto legislativo como costumeiro, normalmente existiu dentro dos par6ametros exigidos e desejados pelas Ordenações Manuelinas e Filipinas, sem com elas chocar-se." (WEHLING, p. 68). 
diretrizes régias confluíssem para o horizonte de seus próprios interesses." (SOUSA, 2007, p. $321)$.

Enquanto hoje se argumenta que municípios não podem ser reconhecidos como entidade federativa porque não possuem Poder Judiciário, naquela época a "justiça concedida municipal" tinha atribuições definidas nas Ordenações (Manuelinas e Filipinas) e na legislação extravagante: "A esfera da justiça concedida municipal limitava-se, pela alçada para ela admitida nas Ordenações, a causas de menor monta. A matéria julgada era de temas cíveis (família, sucessões, propriedade e obrigações contratuais) e criminais.” (WEHLING, p. 44). Mais do que isso:

Pode-se afirmar, assim, que o juiz ordinário teve significativo papel na unidade político-administrativa e jurídica colonial, aplicando o direito português ao mesmo tempo em que possuía, na maior parte das vezes, certa margem de atuação para fazer valer os interesses locais. A escassa tradição consuetudinária, provavelmente explicável pela forte concorrência representada pelas justiças oficial e privada, contribuiu assim para transformar a atividade judicial das câmaras num instrumento de uniformização político-jurídico. Mais uma vez sai reforçada a tese da importância do municipalismo. (WEHLING, p. 69, et seq.).

Para além do aspecto político-jurídico, talvez seja possível aprofundar a pesquisa considerando que a experiência colonial portuguesa pode ter legado o vínculo de cidadania foi marcando a cultura nacional gradativamente ao ponto de, aproveitando um processo constituinte mais democrático, constitucionalizar a importância dos municípios no contexto federativo. Nesse sentido, destaca-se a observação de Luís Fernando Lopes Pereira inspirado em Pietro Costa:

A cidade, apesar das transformações, mantém uma vitalidade e autonomia político-institucional, mantendo certas continuidades, como o nexo que liga o cidadão à comunidade política e mesmo uma autonomia de autogoverno, afinal passa a ter em si mesma os fundamentos de sua legitimidade, não necessitando busca-los fora, experimentando uma nova valorização da ação política dos cidadãos, com uma refiguração que faz da participação política até um valor republicano. Até porque na base de uma antropologia política, pressupõe-se o Príncipe como capaz de se apoderar do objeto do Estado, mas a cidade não pode ser esse objeto. A virtude do príncipe e dos cidadãos se mistura com a política (manutenção do Estado) e afirma a capacidade do sujeito; desta forma a cidadania republicana exige uma virtude própria que coincide com a ação politicamente orienta à salvaguarda da cidade, fazendo com que a relação se reforce. (PEREIRA, p. 62, et seq.) 
Mirado de outros ângulos (à contrapelo!), vislumbra-se que a opção do constituinte brasileiro não seja inédita no plano sociológico, de forma que possa ser tomada como divorciada da realidade nacional que se desenvolveu desde a chegada dos europeus.

Conforme demonstrado, a própria estratégia colonizadora portuguesa se beneficiava do desenvolvimento do poder local que se desenvolveu e permaneceu de forma que pode ser relacionado com a atual distribuição de competência da federação brasileira, especialmente com a descentralização político-administrativa e autonomia municipal nos assuntos de interesse local.

Analisando o desenvolvimento político-jurídico nacional é possível verificar que, apesar da afetação do municipalismo no período imperial e nos períodos de ditadura, a repartição de competência republicana não se distancia tanto das concessões que o reino fazia à colônia, sendo possível afirmar que há mais permanência do que rupturas na história institucional brasileira.

\section{CONCLUSÃO}

Independente dos debates conceituais que podem ser alimentados pelos estudiosos do Direito do Estado, sobre a situação constitucional sui generis dos municípios na federação brasileira, não se pode negar o alto grau de descentralização do poder e de autonomia local.

Conforme demonstrado, tal arranjo não é resquício do período imperial e foi profundamente afetado nos períodos de ditadura. Em oposição, fortaleceu-se nos períodos de democracia, especialmente sob a égide da atual Constituição. Essa constatação já possibilita relacionar o poder local com o desenvolvimento da democracia, em outros trabalhos.

O resgate da administração portuguesa no período colonial indica a possibilidade de desenvolvimento de cultura político-jurídica que permitiu o desenvolvimento do modelo de poder local que foi resgatado - e vem sendo impulsionado! - pelo constituinte de 1988.

Sabendo que nossa realidade desafia aquele modelo tradicional de federação instituída nos Estados Unidos da América no final do século XVIII, os limites deste trabalho só permitem esperar que tenha sido possível provocar aqueles que acreditam na utilidade do estudo da história dos municípios e da administração portuguesa no Brasil dos tempos coloniais. Também daqueles interessados nos temas da cidadania e da democracia; nas reflexões sobre as permanências culturais no exercício do poder local; nos papeis das elites e 
dos excluídos; nos papeis das instituições coloniais e destas republicanas (dos concelhos camarários aos conselhos municipais).

Vislumbra-se, enfim, vasto campo de pesquisa nas áreas do Direito Público e da Ciência Política que podem se beneficiar com as contribuições da História, da Sociologia e da Antropologia. Uma coisa parece mais clara agora: é possível que haja muito mais de herança lusitana daquilo que se pode enxergar no brilho dos pelos escovados por interesses dissociados da historiografia mais comprometida.

\section{REFERÊNCIAS}

BONAVIDES, Paulo. Curso de Direito Constitucional. 6a ed. São Paulo: Atlas, 2004. CARVALHO, José Murilo de. Os Bestializados : o Rio de Janeiro e a República que não foi. $3^{\text {a }}$ ed. São Paulo: Companhia das Letras, 2006.

CASTRO, José Nilo de. Direito municipal positivo. 4a . ed. Belo Horizonte: Del Rey, 1998.

CAVALCANTI, Themístocles Brandão. Teoria do Estado. São Paulo: Revista dos Tribunais, 1977.

HESPANHA, António Manuel. As vésperas do Leviathan : instituições e poder político. Portugal - sec. XVII. Almedina, 1994.

. Guiando a mão invisível : direitos, Estado e lei no liberalismo monárquico português.

Coimbra: Almedina, 2004.

. O direito dos letrados no Império Português. Florianópolis: Boiteux, 2006.

LARA, Silvia Hunold. Fragmentos setecentistas : escravidão, cultura e poder na América portuguesa. São Paulo: Companhia das Letras, 2007

LOPES PEREIRA, Luís Fernando. Discurso histórico e Direito. In: FONSECA, Ricardo Marcelo (org.). Direito e discurso : discursos do direito. Florianópolis: Boiteux, 2006, p. 131137.

Súditos d'El Rey na América portuguesa: Monarquia corporativa, virtudes cristãs e ação judicial na Villa de Nossa Senhora da Luz dos Pinhais de Curitiba no Século XVIII. Revista do Instituto Histórico e Geografico Brasileiro, Rio de Janeiro, v. 452, p. 51-86, 2011.

MEIRELLES, Hely Lopes. Direito municipal brasileiro. $6^{\mathrm{a}}$ ed., $3^{\mathrm{a}}$ tir. São Paulo: Malheiros, 1993.

SILVA, José Afonso da. Aplicabilidade das normas constitucionais. $3^{\text {a }}$ ed. São Paulo: Malheiros, 1999. 
SOARES, Antonio Carlos Otoni. A instituição municipal no Brasil. São Paulo: Revista dos Tribunais, 1986.

SOUSA, Avanete Pereira. Poder local e autonomia camarária no Antigo Regime : o Senado da Câmara da Bahia (século XVIII). In: BICALHO, Maria Fernanda; FERLINI, Vera Lúcia Amaral (orgs.). Modos de governar : idéia e práticas políticas no Império Português - séculos XVI-XIX. $2^{a}$ ed., São Paulo: Alameda, 2007.

SOUSA, Octávio Tarquínio. A vida de Dom Pedro I. Rio de Janeiro: Liv. José Olympio, 1972.

SOUZA, Laura de Mello e. O Sol e a sombra : política e administração na América portuguesa do século XVIII. São Paulo : Companhia das Letras, 2006.

TEMER, Michel. Elementos de direito constitucional. $8^{\mathrm{a}}$. ed. São Paulo: Revista dos Tribunais, 1991.

VAINFAS, Ronaldo (org.). Dicionário do Brasil Colonial (1500-1808). Rio de Janeiro: Objetiva, 2001.

WEHLING, Arno. WEHLING, Maria José. Direito e justiça no Brasil colonial : o Tribunal da Relação do Rio de Janeiro (1751-1808). Rio de Janeiro: Renovar, 2004. 